\title{
The Relationship of Physical Activities on Obesity in Adults in Indonesia
}

\author{
Sudikno $^{1}$, Elisa Diana Julianti ${ }^{1}$, Yunita Diana Sari ${ }^{1}$, Yurista Permana Sari ${ }^{1}$ \\ ${ }^{1}$ Center of Research and Development of Public Health Effort, Central Jakarta 1056, Indonesia \\ "Corresponding author. Email: onkidus@gmail.com
}

\begin{abstract}
The problem of obesity in Indonesia has been on an upward trend in the last three decades. This study aims to determine the relationship of physical activity with obese in adults in Indonesia. This study used Riskesdas 2013 data. The study design was cross-sectional. Sample were adults aged 20 years and above in Indonesia. A number of samples analyzed were 553 546. Result of the analysis showed that the prevalence of obese was found to be 31.2 percent, while physical inactivity was 64.4 percent. The results of logistic regression analysis showed that a relationship of physical activity with obese in adults. Subjects with physical inactivity had risk of obesity by 1.54 times compared to subjects whose physical activity was sufficient after being adjusted by gender and age. Conclusion: This study showed that relationship between physical inactivity and an increase obese on adults. Recommendation: It is necessary to prevent and control obese by doing sufficient physical activity in the workplace, as well as in the household every day on an ongoing basis. In addition, support is needed from the government related to the provision of playgrounds, safe city parks for the implementation of physical activity for the community.
\end{abstract}

Keywords: physical activity, obese, adults

\section{INTRODUCTION}

Obesity in developing countries, including low and middle income economies, has a lower prevalence rate than developed countries, but has experienced an increase in prevalence since 1990 three times higher than in developed countries [1].

Prevalence of obesity in Indonesia also showed an increase from year to year. Study in 12 districts had a obesity prevalence of 12.2 percent [2]. The prevalence of obesity in adults (> 18 years) in 2018 is 13.6 percent, higher than in 2013 (11.5\%) and in 2007 (8.6\%) [3][4][5].

According to WHO (2000), health risks associated with obesity will increase in line with the increase in BMI. Low risk (BMI <18.5 kg / m2), moderate risk (BMI 18.5-24.9 $\mathrm{kg} / \mathrm{m} 2$ ), high risk (BMI 25.0-29.9 kg / m2), moderate risk (BMI 30.0-34.9 kg / m2), severe risk (BMI BMI 35.0-39.9 $\mathrm{kg} / \mathrm{m} 2$ ), and very heavy risk (BMI $40 \mathrm{~kg} / \mathrm{m} 2$ or more) [6].

One of the factors that influence obesity is lack of physical activity, in addition to other factors such as: consumption of high-fat foods, excess food consumption, age, gender, psychological / stress factors, smoking behavior, alcohol consumption, and nervous system disorders [7][8]. This study was an advanced analysis that has been done before, which further analyzes the relationship between physical activity and obesity in adults [9]. This study aimed to determine the relationship of physical activity to obesity in adults.

\section{METHOD}

This study used secondary data from the Basic Health Research (Riskesdas) 2013. Basic Health Research 2013 was a survey with a cross-sectional design. The population in this study were all household members in Basic Health Research 2013 who were aged 20 years and over. While the sample is all household members aged 20 years and over with no physical and mental disability criteria, the sample of women was not pregnant. The number of samples analyzed was 627259 people. After correction of the outliers, height, weight, and completeness of the data, the number of samples analyzed was 553546 .

Data analyzed in Basic Health Research 2013 were taken from the household questionnaire (RKD13.RT) which included a region, information on household members (gender, age, marital status, region, education, economic status. Basic Health Research 2013 used the ownership index calculation approach, while from individual questionnaires (RKD13.IND) were smoking habits, physical activity, eating habits (instant noodles, vegetables, fruit, biscuits, bread, and fatty foods), measurements (body weight, height). Measurement of body weight of subjects aged 25-65 years using a digital weight scale brand "Fesco" with the accuracy of $0.1 \mathrm{~kg}$, 
"Multifunction" with a capacity of measuring two meters which is calibrated every day, then for height measurement is measured by measuring instrument height This study has obtained ethical approval from the Health Research Ethics Commission, the Indonesian Ministry of Health's with the number: LB.02.01 / 5.2 / KE.006 / 2013. Data processing begins by calculating BMI in accordance with the BMI category according to WHO (2000), obese criteria if BMI is $\geq 25 \mathrm{~kg} / \mathrm{m}^{2}$ [6][10]. Physical activity variables after calculation based on Global Physical Activity Questionnaire (GPAQ) were categorized into $<600$ MET and $\geq 600$ MET [11]. Data analysis was carried out in stages, namely univariate, bivariate, and multivariate analyzes. Univariate analysis is intended to determine the distribution of values of each variable. While the bivariate analysis aims to determine the relationship of the dependent variable, namely the nutritional status variable with the independent variable using the Chi-square test and logistic regression. Furthermore multivariate analysis was performed to determine the relationship of the main independent variable (physical activity) to the nutritional status of obesity controlled with other independent variables using multivariate logistic regression analysis. Multivariate analysis was performed using logistic regression analysis. Variables with a significant value of $p<0.25$ in the bivariate analysis were included in the multivariate candidate model. All analyzes use statistical software.

\section{RESULTS AND DISCUSSION}

\section{Results}

Table 1 showed that the prevalence of obese as much as 31.2 percent. Subjects with sufficient activity were only 35.6 percent. Percentage of males were 47.4 percent and females were 52.6 percent. According to the age group it is known that subjects with an age group of 20-34 years were only 9.4 percent. The highest age group was found in subjects with an age group of 35-44 years, which was 27.1 percent. Most of the subjects with married status 80.5 percent, were single $(12.7 \%)$, and widowed 6.8 percent. Most subjects in rural areas $(53.1 \%)$, according to economic status, subjects in quintile 1 were 17.2 percent, and quintile 2 were 18.7 percent. Whereas in the quintile groups 3, 4, and 5 were 20.3 percent, 21.5 percent and 22.3 percent respectively. According to the level of education, most of them are still primary school and below, which is 48.8 percent, while the subjects with higher education are only 8.5 percent.

Table 1. Characteristic subject base on obesity status, physical activity, and socio demography

\begin{tabular}{cccc}
\hline Characteristic & & $\mathrm{n}$ & $\%$ \\
\hline Obesity status & Normal & 381097 & 68.8 \\
& Obese & 172449 & 31.2 \\
Physical activity & Sufficient & 197235 & 35.6 \\
& Inactive & 356311 & 64.4 \\
Gender & Males & 262644 & 47.4
\end{tabular}
and accuracy of $0.1 \mathrm{~cm}$.

\begin{tabular}{cccc}
\hline Characteristic & & $\mathrm{n}$ & $\%$ \\
\hline \multirow{3}{*}{ Age groups (y) } & Females & 290902 & 52.6 \\
& $20-24$ & 52290 & 9.4 \\
& $25-34$ & 129820 & 23.5 \\
& $35-44$ & 150144 & 27.1 \\
Marital status & $45-54$ & 120025 & 21.7 \\
& $55+$ & 101267 & 18.3 \\
& Single & 70324 & 12.7 \\
Region & Widowed & 37767 & 6.8 \\
& Married & 445455 & 80.5 \\
& Urban & 293714 & 53.1 \\
& Rural & 259832 & 46.9 \\
& Quintile 1 & 95036 & 17.2 \\
& Quintile 2 & 103517 & 18.7 \\
& Quintile 3 & 112625 & 20.3 \\
& Quintile 4 & 119137 & 21.5 \\
& Quintile 5 & 123231 & 22.3 \\
& < Primary & 270351 & 48.8 \\
& Junior high & 94448 & 17.1 \\
& Senior high & 141738 & 25.6 \\
& University & 47009 & 8.5 \\
\hline \multirow{2}{*}{ Educational level } & & &
\end{tabular}

From Table 2 it was known that subjects who smoked were 32.8 percent, and past smokers 4.6 percent. Most subjects consumed instant noodles 1-6 times/week $(66.4 \%)$. Subjects who consumed vegetables every day were 59.2 percent. While the fruit consumption of most subjects were 1-6 times /week (75.2\%). Likewise in the consumption of biscuits, bread, and fatty foods, most subjects are 1-6 times/week.

Table 2. Characteristic subject base on smoking status and eating habits

\begin{tabular}{|c|c|c|c|c|}
\hline Characteristic & & & $\mathrm{n}$ & $\%$ \\
\hline \multirow[t]{3}{*}{ Smoking status } & Current smoker & 181827 & 32.8 & \\
\hline & Past smoker & 25390 & 4.6 & \\
\hline & Never smoked & 346329 & 62.6 & \\
\hline \multirow[t]{3}{*}{ Instan noodles } & $>=1$ time per day & 45676 & 8.3 & \\
\hline & 1-6 time/week & 367671 & 66.4 & \\
\hline & Seldom/Never & 140199 & 25.3 & \\
\hline \multirow[t]{3}{*}{ Vegetables } & Never & 6401 & 1.2 & \\
\hline & 1-6 time/week & 219533 & 39.7 & \\
\hline & Everyday & 327612 & 59.2 & \\
\hline \multirow[t]{3}{*}{ Fruits } & Never & 72130 & 13.0 & \\
\hline & 1-6 time/week & 416539 & 75.2 & \\
\hline & Everyday & 64877 & 11.7 & \\
\hline \multirow[t]{3}{*}{ Biscuit } & Seldom/Never & 187485 & 33.9 & \\
\hline & 1-6 time/week & 297059 & 53.7 & \\
\hline & $>=1$ time per day & 69002 & 12.5 & \\
\hline \multirow[t]{3}{*}{ Bread } & Seldom/Never & 152987 & 27.6 & \\
\hline & 1-6 time/week & 316835 & 57.2 & \\
\hline & $>=1$ time per day & 83724 & 15.1 & \\
\hline \multirow[t]{3}{*}{ Fatty food } & Seldom/Never & 82745 & 14.9 & \\
\hline & 1-6 time/week & 285337 & 51.5 & \\
\hline & \multicolumn{2}{|c|}{$>=1$ time per day } & 185464 & 33.5 \\
\hline
\end{tabular}


with physical inactivity had potential to obese 1.54 times compared to subjects with sufficient physical activity after being controlled with gender and age group variables.
The bivariate analysis showed that all variables were associated with obesity (Table 3 and Table 4) and included in the multivariate analysis. Table 5 showed that subjects
Table 3. Obesity status base on physical activity and socio demography

\begin{tabular}{|c|c|c|c|c|c|}
\hline \multirow[b]{2}{*}{ Characteristic } & & \multirow[b]{2}{*}{$\begin{array}{c}\mathrm{n} \\
(553546)\end{array}$} & \multicolumn{2}{|c|}{ Obesity status } & \multirow[b]{2}{*}{$\mathrm{p}$} \\
\hline & & & $\begin{array}{c}\text { Normal } \\
(\%)\end{array}$ & $\begin{array}{c}\text { Obese } \\
(\%)\end{array}$ & \\
\hline \multirow[t]{2}{*}{$\begin{array}{l}\text { Physical } \\
\text { activity }\end{array}$} & Sufficient & 197235 & 76.2 & 23.8 & \\
\hline & Inactive & 356311 & 64.8 & 35.2 & 0.000 \\
\hline \multirow[t]{2}{*}{ Gender } & Males & 262644 & 76.5 & 23.5 & \\
\hline & Females & 290902 & 61.9 & 38.1 & 0.000 \\
\hline \multirow{5}{*}{$\begin{array}{l}\text { Age groups } \\
(\mathrm{y})\end{array}$} & $20-24$ & 52290 & 85.0 & 15.0 & \\
\hline & $25-34$ & 129820 & 71.8 & 28.2 & 0.000 \\
\hline & $35-44$ & 150144 & 63.4 & 36.6 & 0.000 \\
\hline & $45-54$ & 120025 & 63.2 & 36.8 & 0.000 \\
\hline & $55+$ & 101267 & 71.5 & 28.5 & 0.000 \\
\hline \multirow[t]{3}{*}{ Marital status } & Single & 70324 & 84.6 & 15.4 & \\
\hline & Widowed & 37767 & 68.9 & 31.1 & 0.000 \\
\hline & Married & 445455 & 66.4 & 33.6 & 0.000 \\
\hline \multirow[t]{2}{*}{ Region } & Urban & 293714 & 73.7 & 26.3 & \\
\hline & Rural & 259832 & 63.4 & 36.6 & 0.000 \\
\hline \multirow{5}{*}{$\begin{array}{c}\text { Economic } \\
\text { status }\end{array}$} & Quintile 1 & 95036 & 80.7 & 19.3 & \\
\hline & Quintile 2 & 103517 & 74.6 & 25.4 & 0.000 \\
\hline & Quintile 3 & 112625 & 69.8 & 30.2 & 0.000 \\
\hline & Quintile 4 & 119137 & 63.5 & 36.5 & 0.000 \\
\hline & Quintile 5 & 123231 & 59.2 & 40.8 & 0.000 \\
\hline \multirow[t]{4}{*}{ Educational } & $<$ Primary & 270351 & 71.8 & 28.2 & \\
\hline & Junior high & 94448 & 68.3 & 31.7 & 0.000 \\
\hline & Senior high & 141738 & 66.6 & 33.4 & 0.000 \\
\hline & University & 47009 & 59.6 & 40.4 & 0.000 \\
\hline
\end{tabular}

Table 4. Obesity status base on smoking status and eating habits

\begin{tabular}{|c|c|c|c|c|c|}
\hline \multirow{3}{*}{$\begin{array}{l}\text { Characteristic } \\
\text { Smoking status }\end{array}$} & \multirow{2}{*}{\multicolumn{2}{|c|}{$\begin{array}{c}\mathrm{n} \\
(553546)\end{array}$}} & \multicolumn{2}{|c|}{ Obesity status } & \multirow[t]{2}{*}{$\mathrm{p}$} \\
\hline & & & \multirow{2}{*}{$\begin{array}{c}\text { Normal } \\
(\%)\end{array}$} & \multirow{2}{*}{$\begin{array}{c}\begin{array}{c}\text { Obes } \epsilon \\
(\%)\end{array} \\
21.5\end{array}$} & \\
\hline & Current smoker & 181827 & & & \\
\hline & Past smoker & 25390 & 67.4 & 32.6 & 0.000 \\
\hline & Never smoked & 346329 & 63.9 & 36.1 & 0.000 \\
\hline \multirow[t]{3}{*}{ Instan noodles } & $>=1$ time per day & 45676 & 70.9 & 29.1 & \\
\hline & 1-6 time/week & 367671 & 69.6 & 30.4 & 0.000 \\
\hline & Seldom/Never & 140199 & 66.3 & 33.7 & 0.000 \\
\hline \multirow[t]{3}{*}{ Vegetables } & Never & 6401 & 70.2 & 29.8 & \\
\hline & 1-6 time/week & 219533 & 71.7 & 28.3 & 0.008 \\
\hline & Everyday & 327612 & 66.9 & 33.1 & 0.000 \\
\hline \multirow[t]{3}{*}{ Fruits } & Never & 72130 & 74.3 & 25.7 & \\
\hline & 1-6 time/week & 416539 & 69.5 & 30.5 & 0.000 \\
\hline & Everyday & 64877 & 58.4 & 41.6 & 0.000 \\
\hline \multirow[t]{3}{*}{ Biscuit } & Seldom/Never & 187485 & 71.2 & 28.8 & \\
\hline & 1-6 time/week & 297059 & 68.4 & 31.6 & 0.000 \\
\hline & $>=1$ time per day & 69002 & 64.5 & 35.5 & 0.000 \\
\hline \multirow[t]{2}{*}{ Bread } & Seldom/Never & 152987 & 72.1 & 27.9 & \\
\hline & $1-6$ time/week & 316835 & 68.5 & 31.5 & 0.000 \\
\hline
\end{tabular}




\begin{tabular}{lccccc} 
& $>=1$ time per day & 83724 & 64.2 & 35.8 & 0.000 \\
Fatty food & Seldom/Never & 82745 & 72.9 & 27.1 & \\
& $1-6$ time/week & 285337 & 69.2 & 30.8 & 0.000 \\
& $>=1$ time per day & 185464 & 66.4 & 33.6 & 0.000 \\
\hline
\end{tabular}

Table 5. Regression logistic multivariate of the relationship physical activity on obesity

\begin{tabular}{ccccccc}
\hline Variables & & $\mathrm{B}$ & Wald & $\mathrm{p}$ & OR & $95 \% \mathrm{CI}$ \\
\hline Physical activity & Inactive & 0.436 & 4146.9 & 0.000 & 1.54 & $1.52-1.56$ \\
Gender & Females & 0.577 & 8286.2 & 0.000 & 1.78 & $1.75-1.80$ \\
Age groups (y) & $25-34$ & 0.811 & 3426.5 & 0.000 & 2.25 & $2.19-2.31$ \\
& $35-44$ & 1.242 & 8409.0 & 0.000 & 3.46 & $3.37-3.55$ \\
& $45-54$ & 1.260 & 8326.2 & 0.000 & 3.52 & $3.43-3.62$ \\
& $55+$ & 0.843 & 3512.8 & 0.000 & 2.32 & $2.26-2.39$ \\
Constanta & & -2.387 & 30749.4 & 0.000 & 0.09 & \\
\hline
\end{tabular}

\section{Discussion}

The results of this study indicate a relationship between physical activity and obesity in adults after being controlled by gender and age group variables. The same results were also obtained from the research of Shayo and Mugusi (2011) with 1249 subjects aged 18-65 years in Tanzania who showed the influence of physical activity with the incidence of obesity [12].

Several studies of physical activity and the incidence of obesity show that subjects with less physical activity have a risk of obesity by 1.04 times (95\% CI: 0.84-1.03) compared to subjects with recommended physical activity. Men with less physical activity have a risk of obesity by 1.39 times (95\% CI: 1.02-1.89), while women with less physical activity have a risk of obesity by 1.28 times $(95 \%$ CI: 0.99-1.65) [13]. Similar results were also found in Kaplan et al. (2003) which states that physical activity is less associated with obesity. Subjects with less physical activity had a risk of obesity by 2.13 times $(95 \%$ CI: 1.81 2.50) compared to subjects with sufficient physical activity. This risk is quite large, both for men and women. The risk of obesity in men with less physical activity is 2.49 times (95\% CI: 1.65-3.75) compared to men with sufficient physical activity. The risk of obesity in women with less physical activity is 1.85 times (95\% CI: $1.65-$ $2.07)$ compared to women with sufficient physical activity [14].

Individual conditions are also influenced by genetic and other biological factors, such as gender, age and hormonal activity, with little or no control. Food factors and physical activity patterns are considered as intermediate factors that are modified which can increase body weight [6]. The environmental changes related to diet and physical activity can cause an obesity epidemic [15]. While Lokuruka (2013) revealed that high calorie intake, high consumption of fatty meat and oily food, high alcohol consumption combined with low physical activity tends to cause obesity [16].

A randomized controlled trial (RCT) study related to the relationship between physical activity and obesity showed a decrease in BMI which varied in the intervention group compared to the control group. Furthermore, the results of the review and meta-analysis have identified several behavioral change techniques related to increased selfefficacy and physical activity. Some supportive techniques for developing effective physical activity interventions are important to consider by adjusting the intervention techniques to be carried out [17].

From the findings of this study it was necessary to prevent and control obese in the community by doing sufficient physical activity at work, as well as in the household every day. In addition, support is needed from the government related to the provision of playgrounds, safe city parks for the implementation of physical activity for the community.

\section{CONCLUSION}

Our study showed that a relationship between physical activity and obesity in adults after being controlled by gender and age group variables.

\section{ACKNOWLEDGMENT}

The authors are grateful to Sandjaja, Dr PH and Idrus Jus'at, $\mathrm{PhD}$ for his helpful comments.

\section{REFERENCES}

[1] Nguyen M, Fleming T, Robinson M, Thomson B, Graetz N, Margono C, Mullany EC, Biryukov S, Abbafati C, Abera SF, et al. 2014. Global, regional, and national prevalence of overweight and obesity in children and adults during 1980-2013: a systematic analysis for the Global Burden of Disease Study 2013. Lancet. 384 (9945): 766-781

[2] Kodyat BA, Minarto, Raoef R, Pardede LV, Sianturi G, Iryanis. Survei Indek Massa Tubuh (IMT) di 12 Kotamadya, Indonesia. Gizi Indon. 1996; 21: 52-61.

[3] Departemen Kesehatan RI. Laporan Hasil Riset Kesehatan Dasar Tahun 2007. Jakarta (ID): Depkes RI; 2008. 
[11] WHO. Global Physical Activity Questionnaire (GPAQ). www.who.int/chp/steps

[12] Shayo GA, Mugusi FM. 2011. Prevalence of obesity and associated risk factors among adults in Kinondoni municipal district, Dar es Salaam Tanzania. BMC Public Health. 11:365. http://www.biomedcentral.com/14712458/11/365.

[13] Kruger J, Ham SA, Prohaska TR. 2009. Behavioral Risk Factors Associated With Overweight and Obesity Among Older Adults: the 2005 National Health Interview Survey. Preventing Chronic Disease, Public Health Research, Practice and Policy. 6(1):1-17. www.cdc.gov/pcd/issues/2009/jan/07_0183.htm

[14] Kaplan MS, Huguet N, Newsom JT, McFarland BH, Lindsay J. 2003. Prevalence and Correlates of Overweight and Obesity Among Older Adults: Finding From the Canadian National Population Health Survey. Journal of Gerontology: Medical Sciences. 8A(11): 1018-1030.

[15] Apovian CM. 2010. The causes, prevalence, and treatment of obesity revisited in 2009: what have we learned so far? Am J Clin Nutr. 91(suppl):277S-9S.

[16] Lokuruka M. 2013. A Literature Review of Role of Obesity in Adult Health with Reference to Africa. ajfand. 13(1): 7088-7104. 